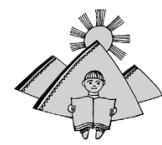

doi: $10.15330 /$ msuc.2019.20.83-88
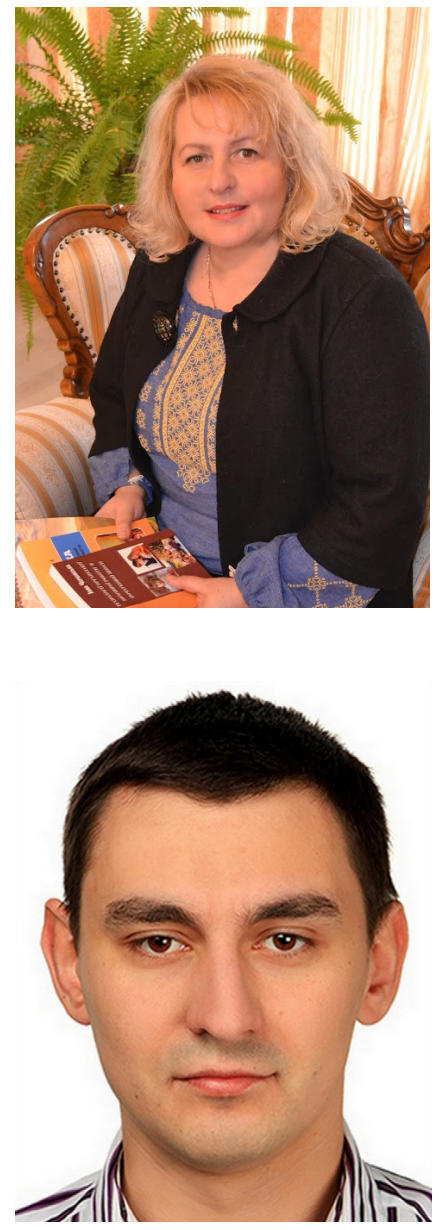

\section{Інна Червінська,}

кандидат педагогічних наук, доцент кафедри

педагогіки початкової освіти,

ДВНЗ «Прикарпатський національний університет

імені Василя Стефаника»

(м. Івано-Франківськ, Україна)

\section{Inna Chervinska,}

$\mathrm{PhD}$ in Pedagogy, Associate Professor,

Department of Pedagogy of Primary Education, Vasyl Stefanyk Precarpathian National University

(Ivano-Frankivsk, Ukraine))

inna.chervinska@pnu.edu.ua

ORCID ID 0000-0003-0745-1413

\section{Андрій Червінський,}

кандидат історичних наук, викладач

кафедри географії та природознавства,

ДВНЗ «Прикарпатський національний університет

імені Василя Стефаника»

(м. Івано-Франківськ, Україна)

\section{Andrii Chervinskyi,}

Candidate of Historical Sciences,

Department of Geography and Natural Sciences,

Vasyl Stefanyk Precarpathian National University

(Ivano-Frankivsk, Ukraine))

andrii.chervinskyi@pnu.edu.ua

ORCID ID 0000-0002-2128-196X

удК 332.14:339.477

\title{
РЕГІОНАЛЬНІ ОСОБЛИВОСТІ СОЦІОКУЛЬТУРНОГО ПРОСТОРУ ГІРСЬКОї ШКОЛИ
}

Анотація. У статті методологічно обґрунтовано та визначено регіональні особливості та освітній потенціал соціокультурного простору гірської школи Карпатського регіону.

Автори розкривають сутність соціокультурного простору як одного зі складників формування простору певного регіону та наголошують, що дефініція «простір» $€$ найбільш придатною до опису феноменів, які мають якісні характеристики протяжності, осмисленості та представництва.

Метою публікації є опис регіональних особливостей соціокультурного простору гірської школи у контексті забезпечення сталого розвитку України.

До провідних завдань дослідження автори відносять:

- виокремлення освітніх, соціально-економічних та інших проблем гірських регіонів;

- визначення шляхів підвищення ефективності діяльності та якості надання освітніх послуг освітніми закладами гірських регіонів;

- підвищення рівня соціокультурної грамотності, формування екологічної свідомості та критичного мислення жителів гірських територій;

- розкриття регіональних особливостей соціокультурного простору гірської школи.

Методологія дослідження включає загальнонаукові методи дослідження: порівняння й аналогія, аналіз і синтез, дедукція та індукція, методи абстракції, класифікації, систематизації, історичний метод.

Вказано на розкриття особливостей регіонів України як відносно самостійних одиниць, які склалися на основі та внаслідок взаємодії територіальних і природних умов, спільності історії, культури і мови, демографічних, соціальних та економічних показників.

Ключові слова: соціокультурний простір, регіональні особливості, Карпатський регіон, освітній потенціал, освіта, гірська школа. 


\section{REGIONAL FEATURES SOCIO-CULTURAL SPACE OF THE MOUNTAIN SCHOOL}

Abstract. In the article the regional peculiarities and educational potential of socio-cultural space of the mountain school of the Carpathian region are methodologically substantiated and defined.

The authors reveal the essence of socio-cultural space as one of the constituents of shaping the space of a certain region and emphasize that the definition of "space" is the most suitable for describing phenomena that have qualitative characteristics of extent, meaningfulness and representation.

The purpose of the study is to describe the regional features of socio-cultural space of the mountain school in the context of ensuring sustainable development of Ukraine.

The leading objectives of the study include:

- isolation of educational, socio-economic and other problems of mountain regions;

- identifying ways to improve the efficiency and quality of educational services to educational institutions in mountain regions;

- increase of the level of socio-cultural literacy, formation of ecological consciousness and critical thinking of inhabitants of mountain areas;

- disclosure of regional peculiarities of socio-cultural space of the mountain school.

Research methodology includes general scientific research methods: comparison and analogy, analysis and synthesis, deduction and induction, methods of abstraction, classification, systematization, historical method.

It is pointed out that the features of the regions of Ukraine are revealed as relatively independent units, formed on the basis and due to the interaction of territorial and natural conditions, common history, culture and language, demographic, social and economic indicators.

Keywords: socio-cultural space, regional features, Carpathian region, educational potential, education, mountain school.

\section{ВСТУП}

Постановка проблеми. У контексті інноваційних наукових підходів сьогодення, регіоналізація виступає необхідною реальністю соціально-політичного устрою нашої країни, провідним чинником сталого розвитку, умовою забезпечення рівного доступу до якісної освіти жителів важкодоступних та віддалених регіонів, інноваційним способом оновлення державно-громадського управління нашої держави. За останні десятиліття модернізація та реформування системи освіти характеризується, з однієї сторони, - посиленням відповідальності регіонів за якість освіти та розвиток освітньої інфраструктури, а, з іншої, - необхідністю її інтеграції в світовий освітній простір.

Розвиток системи освіти визначено одним з основних пріоритетів гуманітарного розвитку регіону Українських Карпат. Однак, поряд з цим спостерігаються внутрішньо-регіональні диспропорції, які вимагають комплексного суспільно-географічного та соціокультурного дослідження.

Аналіз останніх досліджень і публікацій. Питаннями регіональної освітньої політики, а зокрема оцінкою ринків освітніх послуг займалися науковці: А. Антохов, С. Архипова, В. Власов, Л. Пшенична, Л. Семів, Ю. Ходикіна, Л. Шевченко та ін. Теоретичним та прикладним аспектам дослідження регіону Українських Карпат з урахуванням різноманітних методологічних підходів, присвячені праці вітчизняних та зарубіжних науковців (А. Балян, Б. Гершунский, Ю. Гладкий, М. Долішній, Ф. Дюла, М. Лендєл, М. Лаврів, А. Мельник, М. Козоріз та ін.).

МЕТА І ЗАВДАННЯ ДОСЛІДЖЕННЯ. Метою дослідження $€$ опис регіональних особливостей соціокультурного простору гірської школи у контексті забезпечення сталого розвитку України.

До провідних завдань дослідження відносимо:

- виокремлення освітніх, соціально-економічних та інших проблем гірських регіонів;

- визначення шляхів підвищення ефективності діяльності та якості надання освітніх послуг освітніми закладами гірських регіонів;

- підвищення рівня соціокультурної грамотності, формування екологічної свідомості та критичного мислення жителів гірських територій;

- розкриття регіональних особливостей соціокультурного простору гірської школи.

\section{МЕТОДИ ДОСЛІДЖЕННЯ}

Методологія дослідження включає загальнонаукові методи дослідження: порівняння й аналогія, аналіз і синтез, дедукція та індукція, методи абстракції, класифікації, систематизації, історичний метод. Метод діалектики, який належить до філософських, передбачає вивчення всіх явищ і процесів, які відбуваються у гірському регіоні, у тому числі й суспільно-географічних, у постійній зміні, розвитку та взаємозв'язку. Порівняння як метод, дозволяє виявити найбільш суттєві деталі, риси, подібності та відмінності між різними об'єктами, явищами та процесами на різних територіях певного регіону. Методи аналізу та синтезу застосовувалися під час вивчення просторово-часових характеристик та функціональних особливостей певного регіону.

\section{РЕЗУЛЬТАТИ ДОСЛІДЖЕННЯ}

Українські Карпати як гірський регіон, що характеризується високим природно-ресурсним потенціалом, унікальними етнокультурними традиціями та здобутками, важливим геополітичним розташуванням, мають велике значення для соціокультурного, освітнього, соціально-економічного розвитку Закарпатської, Львівської, Івано-Франківської та Чернівецької областей, на території яких вони розташовані. 
Адже як вказано у «Концепції розвитку гірських територій Українських Карпат»: «Більшість гірських територій, які розташовані на висоті 400 метрів над рівнем моря і вище, є важкодоступними. Ресурсний потенціал зазначених територій, на яких проживає 978 тисяч громадян у 715 населених пунктах, не реалізований, а рівень їх соціальноекономічного розвитку значно нижчий, ніж в цілому в Україні, що призводить до низької якості життя населення, до нарощування диспропорцій в системі господарських комплексів та погіршення інвестиційної привабливості гірських територій, зростання диференціації основних соціально-економічних показників, посилює депресивність та дотаційність таких територій, призводить до погіршення їх екологічного стану, втрати потенціалу для відновлення розвитку та стримує збалансований розвиток областей, на території яких розташовані Карпати» («Концепція розвитку гірських територій Українських Карпат», 2019).

У словнику з регіональної політики наведено наступне тлумачення цього поняття: «Регіон (франц. region, від лат. region - область, район) - територія, яка відрізняється від інших територій за рядом ознак і характеризується певною цілісністю та взаємопов'язаністю її складових елементів. Регіони можуть бути будь-якого розміру - від міста (або району у великому місті) до величезних регіонів всередині континенту («Словник з регіональної політики»).

3 точки зору практичної ідентифікації регіону, під цим поняттям у найбільш широкому сенсі слід розуміти певну територію, яка характеризується обов'язковою наявністю внутрішніх зв'язків (економічних, екологічних, соціальних, етнокультурних тощо), і ці зв'язки є більш міцними й тісними, ніж зв'язки цієї території з іншими територіями чи державою в цілому.

І. Металова вказує, що педагогічні дослідження трактують регіон як «єдиний цілісний освітній комплекс, інтегруючий в собі весь освітній потенціал адміністративно-територіальної структури, його кадрові, науково-методичні, матеріально-технічні та інші складові (Металова И.Г., 2009).

Освіта виступає важливим соціокультурним феноменом, який формує загальну культуру й освіченість підростаючого покоління, сприяє засвоєнню духовного, матеріального й інтелектуального потенціалу, який був накопичений людською цивілізацією в процесі еволюційного розвитку й націлений на подальший прогрес суспільства.

Окрім того, як зазначає дослідник Б. Гершунський, «сьогодні освіта є вагомим соціальним інститутом, який сприяє економічному, соціальному, культурному функціонуванню і вдосконаленню суспільства 3 допомогою спеціально організованої цілеспрямованої соціалізації та інкультурації окремих індивідів, який виражений у системі, що включає освітні установи, органи управління ними, освітні стандарти, які забезпечують їх функціонування і розвиток» (Гершунский Б.С., 1998, С. 615).

Також для нашого дослідження складає особливу зацікавленість, виокремлення дослідником чотирьох аспектів змістовного трактування поняття «освіта»: освіта як цінність; освіта як система; освіта як процес; освіта як результат. Зазвичай під терміном «освіта» розуміють «...спеціальну сферу соціального життя, унікальну систему, своєрідний соціокультурний феномен, який сприяє нагромадженню знань, умінь і навичок, інтелектуальному розвитку людини» (Гершунский Б.С., С. 615).

У такому контексті освіта виступає загальноприйнятим понятяя, яке одночасно трактується як педагогічний процес, і як важливе соціальне явище без якого неможливий подальший соціальний прогрес, і як велика суспільна система, яка забезпечує загальноцивілізаційний рух людства.

Регіональні заклади загальної середньої освіти (3ЗСО), володіючи загальними інваріантними характеристиками, у своєму становленні та розвитку залежать від низки чинників, визначених географічною, економічною, соціокультурною, національно-етнічною, полікультурною специфікою. У сучасних умовах розвитку суспільства, до провідних зовнішніх чинників впливу на розвиток освітнього закладу як такого, і системи освіти загалом, відносяться - глобалізація та інтернаціоналізація, які проявляються не тільки у посиленні взаємозв'язків і взаємозалежностей господарських механізмів окремих країн, а й у формуванні глобального освітнього простору.

Становлення, розвиток, компонентна структура та ефективне функціонування закладів загальної середньої освіти регіону Українських Карпат залежать від цілої низки показників, які класифікують за різними ознаками:

- за природою дії та взаємодії: зовнішні та внутрішні;

- за змістом: природні, історичні, суспільні, демографічні, економічні;

- за характером впливу: прямі та непрямі (або опосередковані);

- за рівнем впливу: глобальні, національні, регіональні, локальні та особистісні;

- за результатом впливу: позитивні та негативні (Кравців В.С., 2013).

Освітні заклади гірського регіону, перебуваючи у постійній динаміці та зазнаючи певних трансформацій у своєму розвитку й діяльності, чуттєво реагують навіть на незначні зміни зовнішнього середовища. Відповідно вони намагаються адаптуватися до потреб зовнішнього середовища, ринку праці, освітніх запитів суспільства, які швидко змінюються. Однак, варто зауважити, що й освітні заклади, які в сукупності складають багаторівневу систему освіти також активно впливають на формування соціокультурного простору в якому вони перебувають.

Діяльність цілісної системи освітніх закладів здійснює суттєвй вплив на розвиток загальносвітових інтеграційних процесів, що стосуються регіонального розвитку.

Важливу роль у становленні, розвитку та функціонуванні закладів загальної середньої освіти відіграють внутрішні чинники, які можна умовно поєднати у певні блоки: історичні, демографічні, економічні, інституціональні, управлінські, соціально-культурні, просторові, природні.

Опосередкований вплив на мережу освітніх закладів та їх просторову організацію здійснюють природні чинники, серед яких необхідно відзначити: рельєф, висоту над рівнем моря, кліматичні та гідрологічні умови території. Вказані 
чинники природного середовища впливають на особливості освоєння регіону, конфігурацію забудови населених пунктів, транспортну доступність населення до освітніх закладів, розташованих на цій території, загальну кількість та щільність населення тощо.

В цьому контексті, до провідних функцій реалізації регіональної освітньої політики відносять:

- освітня (підготовка фахівців відповідного профілю та зростання конкурентоспроможності на ринку освітніх послуг);

- економічна (діяльність освітніх закладів та закладів позашкільної освіти як прибуткових підприємств, які забезпечують надання освітніх послуг);

- $\quad$ культурологічна (підвищення загальноосвітнього та соціокультурного рівня освіченості та грамотності населення гірських регіонів);

• $\quad$ соціальна (задоволення потреб суспільства у творчій та професійній реалізації певних категорій населення, здобутті відповідного соціального статусу);

інформаційна (належний доступ до інформаційних ресурсів, повна інформація щодо пропозицій та послуг, визначення кон'юнктури на ринку освітніх послуг);

• інтеграційна (розвиток академічної мобільності, входження вітчизняних закладів загальної середньої освіти до освітнього простору Європи та світу) (Шендер А. Р., 2013).

Оскільки освіта у сучасному геокультурному просторі прямо або опосередковано впливає практично на всі сфери людської діяльності, формується певний освітній простір різних ієрархічних рівнів - від глобального до локального. Це поняття пропонуємо трактувати як сукупність всіх освітніх закладів, а також інших установ та організацій, що надають освітні послуги населенню в межах певної території. В залежності від розмірів території, на якій розміщені заклади освіти, можна розглядати різні ієрархічні рівні освітнього простору.

Так, зокрема, заклади освіти, які розміщені в межах законодавчо визначеного адміністративного району, об'єднаної територіальної громади, формують локальний (районний) освітній простір, у межах адміністративної області регіональний (обласний) освітній простір, у межах певної країни - національний освітній простір, у межах конкретного континенту - континентальний освітній простір, у межах всієї планети - глобальний (планетарний) освітній простір.

Вказана ієрархія глобального освітнього простору базується на основі істотних відмінностей системи освіти різних країн та континентів, які стосуються не тільки змісту освіти, а й різних соціальних показників - таких як рівень розвитку, рівень освіти населення, компонентної, територіальної та функціональної структури тощо.

Українські Карпати як гірський регіон, що характеризується високим природно-ресурсним потенціалом і важливим геополітичним розташуванням, мають велике значення для соціально-економічного розвитку Закарпатської, Львівської, Івано-Франківської та Чернівецької областей, на території яких вони розташовані. Регіон Українських Карпат є одним із провідних наукових, освітніх центрів України. Він має високий освітній потенціал серед інших регіонів країни.

Більшість гірських територій, які розташовані на висоті 400 метрів над рівнем моря і вище, є важкодоступними. Ресурсний потенціал зазначених територій, на яких проживає 978 тисяч громадян у 715 населених пунктах, не реалізований, а рівень їх соціально-економічного розвитку значно нижчий, ніж в цілому в Україні, що призводить до низької якості життя населення, до нарощування диспропорцій в системі господарських комплексів та погіршення інвестиційної привабливості гірських територій, зростання диференціації основних соціально-економічних показників, посилює депресивність та дотаційність таких територій, призводить до погіршення їх екологічного стану, втрати потенціалу для відновлення розвитку та стримує збалансований розвиток областей, на території яких розташовані Карпати (Кравців В.С., 2013). У рамках зазначеного дослідження, ми дотримуємося точки зору, що міждисциплінарний характер вивчення феномена соціокультурного простору певного регіону зумовлює актуальність застосування методик суміжних наукових дисциплін, завдяки яким формуються прикладні методи освітології, культурології, регіонології (регіоналістики), які в комплексі спрямовані на отримання конкретної інформації про соціокультурну практику діяльності певного регіону чи території.

Необхідність сталого розвитку регіону Українських Карпатського викликана освітніми соціальними, культурнопросвітницькими, еколого-економічними проблемами краю. Саме тому провідні чинники збереження унікальних природних комплексів, збалансованого природокористування, поряд з розвитком освітньої, дозвіллєвої, туристичнорекреаційної галузі, екологізацією лісогосподарського комплексу, підвищенням ролі природно-заповідних територій, розглядаються як необхідність збереження етнокультурної спадщини корінного населення (Химинець В.В., 2004).

Загальноприйнята світовим співтовариством Концепція сталого розвитку («Державна програми соціальноекономічного розвитку Карпатського регіону розроблену Інститутом регіональних досліджень НАН України Державна служба статистики України»), з якою пов'язується успішне майбутнє людства, не лише розглядає природну складову, географічне середовище як головну поряд з соціальною та економічною компонентами людського розвитку, а й вимагає стосовно неї цілої низки обмежень, спрямованих на недопущення деструктивних змін у навколишньому природному середовищі.

Дотримання провідних принципів сталого розвитку має свої специфічні особливості та певні відмінності у різних частинах світу, країнах і регіонах, оскільки «не може не враховувати особливості кожної території, включаючи їх природні особливості та специфіку природно-ресурсного потенціалу» (Химинець В.В., 2004).

Певними особливостями вирізняються й країни з гірськими територіями. Впродовж двох десятиліть 3 часу офіційного визнання на Конференції ООН у Ріо-де-Жанейро (1992), Концепції сталого розвитку, чимало зусиль 
науковців, представників органів управління та громадськості зосереджується на вирішенні проблем сталого регіонального розвитку гірських територій, до яких входять і регіон Українських Карпат.

Варіативність застосування зазначеного підходу зумовлена унікальною природною і культурно-етнічною спадщиною, яка зберіглася в гірських регіонах, особливою вразливістю гірських територій до нищівної вирубки лісів, забруднення рік, а також тим, що гори є місцем проживання численних мешканців, для яких вони стали рідними. Для цього регіону Українських Карпат притаманні несприятливі природно-господарські, складні географічні та полікультурні особливості: низькі питомі показники забезпечення орними землями, складна транспортна доступність, віддаленість певних населених пунктів від центрів, складні для господарювання кліматичні й гідрологічні умови, екологічні проблеми. Вказані особливості зумовлені тим, що гірські території поступаються рівнинним за станом соціально-економічного розвитку, доступністю до провідних освітніх та соціально-культурних центрів, несприятливими кліматичними умовами. Таке становище призводить до депопуляційних тенденцій і ставить під загрозу збереження унікального соціокультурного та етнокультурного простору гірських територій (Chervinska I., \& Chervinskyi A., 2018).

Регіон Українських Карпат володіє вагомими показниками для подальшого розвитку завдяки своєму унікальному етнокультурному та природно-ресурсному потенціалу. Довкілля (навколишнє природне середовище) входить до числа складових триєдиної взаємозалежної системи, у якій реалізується модель сталого розвитку. Відповідно роль та значення природних чинників у ї̈ функціонуванні $€$ не менш важливою, ніж соціальних чи економічних (Герасимчук 3. В., 2011).

Також необхідно наголосити на важливості довкілля як середовища проживання членів соціуму, з чим пов'язане поняття «природні умови», «природні ресурси» та їх роль як джерела природних благ для забезпечення належної життєдіяльності соціуму. «Сукупність виявлених і придатних для використання при досягнутому рівні розвитку виробництва природних ресурсів тієї чи іншої території складає його природно-ресурсний потенціал» (Шендер А. Р., 2013). Який розглядається науковцями (М. Лаврук, В.Химинець та ін.) як частина загальнонаціонального багатства країни загалом, так і конкретного регіону зокрема.

Таким чином, врахування природних чинників стану довкілля під час моделювання сталого розвитку гірських територій вкрай важливе, оскільки воно визначає якість життя соціуму, як у контексті його комфортності, так і під час надання якісних освітніх послуг, забезпечення соціальних й економічних потреб. Адже для кожного регіону притаманний специфічний перелік природних чинників із цікавими для дослідників гір особливостями їх прояву.

\section{ВИСНОВКИ ТА ПЕРСПЕКТИВИ ПОДАЛЬШИХ ДОСЛІДЖЕНЬ}

Зазначене вкотре підтверджує, що внутрішні та зовнішні зв'язки гірських шкіл регіону Українських Карпат вирізняються надзвичайним рівнем складності та різноманітністю проявів. Адже територіальна структура освітніх закладів регіону представлена елементами, які функціонують у межах освітнього простору, формами їх зосередження та зв'язками між ними.

Відповідно, основними елементами вказаної територіальної структури можуть виступати - опорні школи, навчально-виховні комплекси, освітні центри та освітні округи, заклади позашкільної освіти та інші підрозділи, які в комплексі зможуть забезпечити надання якісних освітніх послуг населенню в межах певного освітнього простору. Адже система освіти певного регіону вирізняється специфічними територіально-функціональними особливостями, що вирізняють її від інших суспільно-географічних систем.

Подальше вивчення освітнього потенціалу регіону Українських Карпат дасть можливість прослідкувати вплив сукупності чинників на формування регіонального соціокультурного простору.

\section{СПИСОК ВИКОРИСТАНИХ ДЖЕРЕЛ}

Аверкин, В.Н. (2008) Теоретические проблемы регионализации образования. Новгород.

Гершунски, Б.С. (1998) Философия образования для XXI века: в поисках практико-ориентированных образовательных концепций. Москва: Совершенство.

Герасимчук, 3. В. (2011) Стимулювання сталого розвитку регіону: теорія, методологія, практика. Луцьк: РВВ лНТУ.

Долішній, М.І. (2004) Територіальна суспільна система як об'єкт дослідження регіональної економіки. Соціально-економічні дослідження в перехідний період. Зб. наук. праць. (3 Ч.1). НАН України Ін-т регіон. досліджень. Львів.

Декларация конференции ООН по окружающей среде. (1979) Москва: Наука, 7-11.

Державна програми соціально-економічного розвитку Карпатського регіону розроблену Інститутом регіональних досліджень HАН України Державна служба статистики України. URL: :http://www.ukrstat.gov.ua

Журавський, В. С. (2003) Вища освіта як фактор державотворення і культури в Україні. Київ: Ін Юре.

Заставний, Ф. (2010) Економічні райони України. Реалії та перспективи (природно-географічні, історичні, національно-культурні, національно-політичні). Львів: Апріорі.

Закон України «Про статус гірських населених пунктів України» (Закон України № 56/95 від 15.02.1995p.). URL: https://zakon. rada.gov.ua/laws/show

Кравців, В.С. (Ред.) (2013) Карпатський регіон: актуальні проблеми та перспективи розвитку : монографія у 8 томах.(Том 5. Малі міста). Львів.

Концепція розвитку гірських територій Українських Карпат (2019) URL: https:// decentralization.gov.ua/news/10835

Костин, А.К. (2005) Регионализация образования - стратегическое направление образовательной политики. Педагогика, 8, 34-38.

Лапаева, М.Г.\&Лапаев, С.П. Регион как пространственная социально-экономическая система государства. URL: http://vestnik. osu.ru/2012_8/21.pdf. 
Металова, И.Г. (2009) Регионализация профессиональной подготовки учителя сельской школы в ВУЗе (Автореф. дисс. ... д-ра пед. наук); Федеральный институт развития образования. Москва.

Словник з регіональної політики. Інститут регіональних та євроінтеграційних досліджень ЄвроРегіо Україна. URL: http://www. eru.org.ua.

Стратегія розвитку Івано-Франківської області на період до 2020 р URL: http://www.if.gov.ua/files/SP_IF_oblast_4.pdf

Химинець, В.В. (2004) Еколого-економічні засади сталого розвитку Закарпаття. Ужгород.

Шендер, А. Р. (2013) Оцінювання регіональних ринків освітніх послуг у сфері вищої освіти в умовах активного впливу зовнішнього середовища Регіональна економіка, 3, 199-202.

Chervinska. I., \& Chervinskyi A. (2018) Sustainable development of the mountain territory of the Ukrainian Carpathians foreign experience and domestic realities. Journal of Vasyl Stefanyk Precarpathian National University.Scientific edition.Series of Social and Human Sciences. (Vol.5, 1, 9-18).

\section{REFERENCES}

Averkin, V. N (2008) Theoretical problems of regionalization of education. Novgorod

Gershunsky, B.S. 91998) Education Philosophy for the 21st Century: Searching for Practically Oriented Educational Concepts. Moscow: Perfection

Gerasymchuk, Z. V. (2011) Stimulation of Sustainable Development of the Region: Theory, Methodology, Practice: Monograph. Lutsk: RVV LNTU.

Dolishniy, M. I. (2004) Territorial social system as an object of study of regional economy. Socio-economic studies in transition. Coll. Sciences. wark. (No. 3 Part 1). NAS of Ukraine Inst. research. Lviv.

Declaration by the United Nations Conference on the Environment (UNEP). (1979) Moscow: Science. 7-11.

State Programs of Socio-Economic Development of the Carpathian Region developed by the Institute for Regional Studies of NAS of Ukraine State Statistics Service of Ukraine. Retrived from http: //www.ukrstat.gov.ua.

Zhuravsky, V. S. (2003) Higher education as a factor of state formation and culture in Ukraine. Kyiv: In Yure.

Zastavnyi, F. (2010) Economic regions of Ukraine. Realities and perspectives (natural-geographical, historical, national-cultural, national-political). Lviv: A priori.

Law of Ukraine "On the Status of Mountain Settlements of Ukraine" (Law of Ukraine No. 56/95 of 15.02.1995). Retrived from https:// zakon.rada.gov.ua/laws/show (in Ukrainian).

Tailors, V. S. (Ed.) (2013) Carpathian Region: Current Issues and Development Prospects: 8 volume monograph (Vol. 5. Small Cities). Lviv.

Ukrainian Carpathian Mountain Territory Development Concept (2019) Retrived from: https:// decentralization.gov.ua/news/10835 (in Ukrainian).

Kostin, A.K. (2005) Regionalization of education is a strategic direction of educational policy. Pedagogy. No. 8, 34-38.

M. Lapaeva Region as a spatial socio-economic system of the state Retrived from: http://vestnik.osu. ru/2012_8/21.pdf.

Metalova, I. G. (2009) Regionalization of Vocational School Teacher Training in Higher Education: (Candidate's thesis) Federal Institute for the Development of Education. Moscow.

Dictionary of Regional Policy. Retrived from: http://www.eru.org.ua. (in Russian)

Ivano-Frankivsk Region 2020 Development Strategy. Retrived from: http://www.if.gov.ua/files/SP_IF_oblast_4.pdf (in Ukrainian).

Khimynets, V. V. (2004) Ecological and economic principles of sustainable development of Transcarpathia. Uzhgorod.

Sender, A. R (2013) Assessing Regional Markets for Higher Education Education Services in Active Environmental Impacts Regional Economy, 3, 199-202.

Chervinska, I., \& Chervinskyi , A. (2018) Sustainable development of the mountain territory of the Ukrainian Carpathians foreign experience and domestic realities. In Journal of Vasyl Stefanyk Precarpathian National University.Scientific edition.Series of Social and Human Sciences, Vol.5, 1, 9-18. 